\title{
Comparison of Aid Allocation Patterns of Two Emerging Donors: Korea and Greece
}

\author{
Jinhwan $\mathrm{Oh}^{1}$, Jisun Song ${ }^{1} \&$ Se Eun Yim ${ }^{1}$ \\ ${ }^{1}$ Graduate School of International Studies, Ewha Womans University, Seoul, Korea \\ Correspondence: Jinhwan Oh, Graduate School of International Studies, Ewha Womans University, Seoul, Korea. \\ Tel: 82-2-3277-6697. E-mail: joh@ewha.ac.kr
}

\author{
Received: June 7, 2015 Accepted: July 2, 2015 Online Published: September 21, 2015 \\ doi:10.5539/res.v7n12p1 URL: http://dx.doi.org/10.5539/res.v7n12p1
}

\begin{abstract}
This study analyzes how the aid allocation pattern of the OECD DAC's emerging donor Korea is different from that of Greece. By using the dataset of 153 aid recipient countries from 1996 to 2008 and 1987 to 2011 respectively, this study reveals that Greece and Korea display similar patterns of aid disbursement. They favor recipients with higher income level, with larger population, closer trade ties, better social development, protection of freedom and human rights, and nearby located neighbors. However, in case of Korea, this study conjectures that aid fragmentation and obscure processes in approving the ODA-funded projects may be latent challenges in upholding coherent aid practices.
\end{abstract}

Keywords: foreign aid, aid allocation, emerging donors, Korea, Greece

\section{Introduction}

In spite of the global recession, donors have been more forthcoming about their concern for international development cooperation. In 2013 alone, five countries joined OECD's Development Assistance Committee (DAC), which is dedicated towards sustainable development including poverty eradication, pro-poor growth and improvement of living standards. As the first country that transformed oneself from an aid recipient to an aid donor, Korea is now cited as a model for other developing countries striving to witness another miracle in their own nation.

Nevertheless, despite of the international community's huge interests and eyes on the role of Korea in the new paradigm of the international development cooperation, not many studies have been conducted to analyze how Korea is different from the traditional OECD DAC member states. Thus, the aim of the study is to compare how Korea is especially performing differently from Greece, which used to be the last country to join the OECD DAC in 1999 before the entry of Korea in 2010.

In order to analyze and compare how Korea and Greece allocate their aid to partner countries, this study is divided into the following parts. First, it examines the history of receiving and providing the official development assistance (ODA) of Greece and Korea. After analyzing the aid disbursement patterns of the two donors, the second section of the study endeavors to look at the determinants of aid disbursement of Greece and Korea. In this section, the dataset of 153 aid recipient countries from 1996 to 2008 and 1987 to 2011 respectively is used with one regression question involving one dependent variable (ODA disbursement per capita) and various types of explanatory variables. However, in order to investigate deeper analyses and detail findings, this study also examines how the two donors' aid motivations are portrayed in recipient countries that are divided by the income level. In the following third section, the study analyzes what kind of challenges can be encountered based upon the findings depicted in the second section. And finally, the conclusion summarizes the study with offering policy recommendations to Korea.

\section{Greece and Korea's ODA History}

Greece and Korea are the two OECD DAC members who joined in 1999 and 2010, respectively (Note 1). Greece as a somewhat emerging donor in Europe and Korea as a new emerging donor from Asia, they share similarities and differences in certain aspects. Table 1 compares some of the key points of the two countries as donors. 
Table 1. Comparison of Korea and Greece's ODA

\begin{tabular}{lcc}
\hline & Korea & Greece \\
\hline OECD DAC Membership & 2010 & 1999 \\
ODA/GNI (\%) & $0.12 \%(2011)$ & $0.11 \%(2011)$ \\
Net ODA & USD 1.32 Billion (2011) & USD 331 Million (2011) \\
Bilateral: Multilateral (\%) & $73: 27(2011)$ & $18: 82(2011)$ \\
Tied : Untied Aid (\%) & $64: 36(2010)$ & $38: 62(2010)$ \\
2015 Target (ODA/GNI) & $0.25 \%$ & $0.7 \%$ \\
Priority Country (\#) & 26 & 21 \\
Recipient History & 1995 (World Bank) & From WWII to 1980s \\
& 2000 (OECD DAC) & \\
Donor History & 1987 (EDCF) & Hellenic Aid (under MOFA) \\
Main Department & 1991 (KOICA) & \\
\end{tabular}

Source: OECD (2012) Development Co-operation Report and ODA Korea Homepage

The two donors are alike in the sense that they share the history of having been a recipient country. Greece received aid from the international community after World War II to 1980s and Korea received aid from as early as 1945 until it stopped receiving aid from the World Bank in 1995 and was removed from the DAC recipient list in 2000. Both made transformation from a recipient to donor by establishing respective agencies and are allocating around 0.11 percent of its GDP each year. Furthermore, out of their priority countries, each has the tendency to focus on their strategic, regional partners who are Eastern European countries in the case of Greece and East Asian countries for Korea.

However, its aid style is on the opposite. While Korea disburses its aid bilaterally, Greece gives a bulk of its aid to multilateral organizations, mainly to the European Union. Also, whereas around two-thirds of Greek aid is untied, the equivalent share is tied in Korea's case. Moreover, Korea's absolute aid volume is about four times greater than that of Greece. For the aid management system, unlike Greece where Hellenic Aid under the Ministry of Foreign Affairs is in charge, Korea adopts a bifurcated system. That is, the Ministry of Foreign Affairs and Korea International Cooperation Agency, its implementing agency, are in charge of grants and the Ministry of Strategy and Finance and the Economic Development Cooperation Fund of the Korea Export-Import Bank are in charge of concessional loans. 


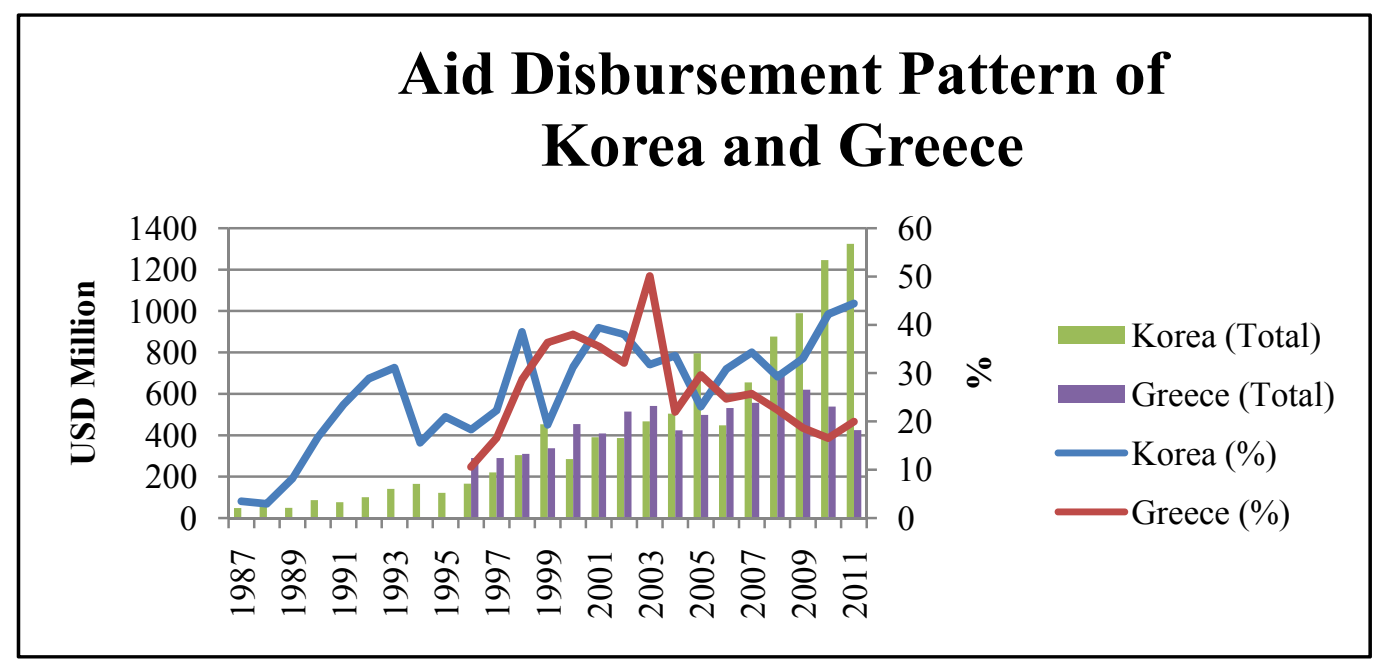

Figure 1. Aid Disbursement Pattern of Korea and Greece

Note. Bilateral flow, Constant Price (2011 USD Million) based), all sectors

Source: ODA disbursement (OECD Statistical Database)

Figure 1 shows the trend of two donors' aid disbursement over the years, from 1987 and 1996 for Korea and Greece, respectively. Whereas Korea began to give aid more than two decades before DAC membership, Greece only gave aid from 1996. The bar graph denotes total disbursement to all recipient countries. In spite of the recent global financial crisis, Korea continued to increase the absolute amount of its aid based on its commitment to reach $0.25 \% \mathrm{GNI} / \mathrm{ODA}$ target for 2015. On the other hand, Greece was unable to recover from the debt crisis in 2009, which led to the gradual downhill of aid from 2008. It is due to this that the analysis for Greek aid was limited to 2008 .

The line graphs represent the percentage of the two donors' aid to their priority countries out of the total aid budget. Both countries strategically opted to focus on nearby countries by having them as partner countries. For instance, out of Korea's 26 partner countries (Note 2), 14 are in Asia and Commonwealth of independent states (OECD, 2012, p. 28). In case of Greece, it has 6 priority regions and partner countries accordingly, two of which are (Balkans and countries of the Black Sea and Middle East) are selected for geographical significance.

It is obvious that Korea continues to allot relatively large share of its aid to its partner countries, reaching up to $44.4 \%$ in 2011 . As for Greece, after reaching the peak of $50.1 \%$ in 2003 , the ratio slowly decreased to $22.4 \%$ in 2008 to $20 \%$ in 2011. Coupled with the fact that the number of Asian countries exceed that of other regions for Korea, it can be argued that Korea's geographical foci is present in both policy and practice. As for Greece, the ratio may be smaller because some of its partner countries are not included as the recipient country list from the OECD. Especially when referring to the result in Table 2, Greece can also be seen to concentrate on its neighboring countries.

Hence, both Korea and Greece display commonalities and dissimilarities in their aid practices and policies. Yet, there have not been many studies that compared these two donors together. While there is a number of studies on Korea's aid determinants (e.g. Kim \& Oh, 2012; Koo \& Kim, 2011; Lee, 2005; Lee 2012; Lee \& Park, 2007; Sohn et al., 2012), Greece's case is often lumped together with other DAC donors rather than dealing it separately as a single case study.

With Korea's DAC membership in 2010 and subsequent domestic efforts thereafter, including the enactment of International Development Cooperation Basic Law and expansion of the aid budget, interest in Korea's ODA has augmented noticeably. This was also reflected in the number of studies that determined motivational factors. Despite varying timeline, most studies conclude that Korea does pursue its economic and commercial interest by choosing recipient countries with larger individual income, population, trade, investment, and growth rate (Kim \& Oh 2012, Koo \& Kim 2011, Lee 2012, Sohn et al., 2011) whereas in certain cases per capita income was negatively correlated when only a certain time period and grant was accounted for (Lee, 2005, p. 15; Lee, 2012, p. 983) or when net aid was used (Koo \& Kim, 2011, p. 170). In case of recipient countries' needs several researches utilized social development indicators such as infant mortality rate, primary education (Lee, 2005; Lee, 2012), and Human Development Index (Sohn et al., 2011, p. 60). These studies found that Korea's grant 
was either insignificant or negatively correlated to such variables, which led them to conclude that humanitarian needs were not strongly prioritized.

As for political, social freedom, the Freedom House Index and/or Political Terror Scale were mostly used as is the case of this study (e.g. Koo \& Kim, 2011; Lee, 2012; Sohn et al., 2011). Like social development, the two indices were either insignificant (Koo \& Kim, 2011; Lee, 2012) or positively correlated (Sohn et al., 2011), which also gives mixed result of Korea not paying much attention or rewarding countries with better governance. Last but not least, Korea's regional interest in Asia was also confirmed in several studies (e.g. Dreher et al., 2011, 1960; Koo \& Kim, 2011, p. 181; Sohn et al., 2011, p. 60). However, this study will go one step further to verify if geographical location still matters in different income groups.

Unlike Korea, studies on Greece are often grouped together as part of DAC donors' aid determinants or were non-existent, the latter due to lack of uncensored data for estimation (Berthélemy \& Tichit, 2004, p. 267). As other DAC donors did from the 1980s, Greece, along with other donors such as Portugal and Spain, showed self-interest in it aid by having strongly positive correlation with the trade ratio in the 1990s (Berthélemy \& Tichit, 2004, pp. 257-258). In another analysis, Greek aid was found to target smaller populated countries, sensitive to policy and institutional environment but insensitive to recipients' debt (Classens et al., 2009, p. 205). The pattern strongly resembled that of most DAC donors whose aid was more geared towards countries with larger per capita income, sound policy environment and more debt especially in early 2000s (Classens et al., 2009, p. 198).

In a recent research by Doucouliagos and Manning (2009) that compared Greek aid between 1996 and 2006 to two new donors, Luxembourg and Portugal, Greece was found to have the largest bandwagon effect, which implies that it conforms to the style of other DAC donors as Greek aid to a recipient country increased in positive proportion to non-Greek aid (p. 16). When the analysis was based on random effects Tobit analysis, Greece was found to allocate more aid to countries with larger export ties and stronger geographical links (p. 19). Such results confirm that Greece employs strong self-interest in its aid.

\section{Determinants on Aid Disbursement}

To examine the determinants of Greece and Korea's aid, this section uses dataset of 153 aid recipient countries from 1996 to 2008 and 1987 to 2011 respectively: 1996 is the year when Greece actually began to disburse ODA and 1987 is when Korea established the Economic Development and Cooperation Fund (EDCF), aid agency in charge of loans. Also, it is the base year for prior studies on Korea's aid determinants (e.g. Kim and Oh, 2012). Korea's aid is analyzed until 2011 which is the latest year for which the data is provided for both donors whereas Greek aid was limited to 2008 to account for the recent debt crisis.

ODA disbursement from the OECD database and scaled down to per capita (Note 3) in constant prices with the base year of 2011 to account for inflation. Moreover, the 153 countries also include those that did not receive any aid from either Greece or Korea but were included to avoid selection bias.

Following is the regression equation with one dependent variable (ODA disbursement per capita) and explanatory variables:

$$
\begin{aligned}
& \operatorname{Ln}\left(O D A_{i t}\right)=\beta_{0}+\beta_{I}\left(\operatorname{Ln}_{-} I N C O M E_{i t-1}\right)+\beta_{2}\left(\operatorname{Ln}_{-} I N C O M E_{i t-1}\right)^{2}+\beta_{3}\left(\operatorname{Ln}_{-} P O P_{i t-1}\right)+\beta_{4}\left(L n_{-} P O P_{i t-1}\right)^{2}+ \\
& \beta_{5}\left(L n_{-} T R A D E_{i t-1}\right)+\beta_{6}\left(\operatorname{Ln}_{-} G R O W T H_{i t-1}\right)+\beta_{7}\left(L I \bar{F} E_{i t-1}\right)+\beta_{8}\left(F H I_{i t-1}\right)+\beta_{9}\left(P T S_{i t-1}\right)+\beta_{10}(R E G I O N)+u_{i t}
\end{aligned}
$$

where

- Ln_Income is the log of per capita GDP in 2000 constant US dollars. The data is from World Bank's World Development Indicators. This variable is indicative of donor's economic interest.

- $\quad(\text { Ln_Income })^{2}$ is the quadratic form of Ln_Income, used by numerous studies on aid determinants (e.g. Alesina and Dollar (2000), Neumayer (2003), Berthélemy and Tichit (2004)). It shows the rate of change as a second order. Both Ln_Income and its quadratic form are lagged by one year.

- Ln_Pop is the log of recipient countries' population with 1 year lag. Data is also from the World Development Indicators.

- $\quad\left(\mathrm{Ln} \_ \text {Pop }\right)^{2}$ is the quadratic form of Ln_Pop used to capture its change.

- $\quad$ Ln_Growth is the annual GDP growth rate from the World Bank with one year lag. 
- $\quad$ Ln_Trade refers to the combination of export and import between each donor and the recipient country. This variable was also scaled down to per capita. For Greece, the data is from Eurostat, the statistical database of European Commission. Both export and import data are valued in Euros under the Standard International Trade Classification was used. In case of Korea, the data is from the Korea Statistical Information Service. It is valued in thousand dollars and is based on the Standard International Trade Classification like Greece. This data is also lagged by one year to avoid potential endogeneity problems. If the correlation of aid and trade is positive, it means donors give more aid to countries with stronger commercial ties, which is also indicative of its pursuit of economic interest.

- Life expectancy (Life) is that of birth, derived from the World Development Indicators. This variable is to measure recipient country's social development status. It is also lagged by a year.

- Freedom House Index (FHI) is the average of political rights and civil liberty. This index is used by scholars (e.g. Lee (2012), Neumayer (2003)) to represent political and civil liberty. Ranged between 1 and 7 with 1 being the most free and 7 the least free, negative correlation is expected is donors reward protection of freedom.

- Political Terror Scale (PTS) is the index that measures physical integrity rights violations globally. In addition to the Freedom House Index, this indicator measures key human rights (Neymayer, 2003: 108; Koo and Kim, 2011). The data is provided from two sources: Amnesty International and the U.S. State Department reports and this study will use data from the former. It is measured from 1 to 5 with 1 being the best and 5 the worst. Hence, correlation should be negative like the Freedom House Index.

- Region is a dummy variable to distinguish Central and Eastern European countries and Southeast Asian countries, respectively. For the former, the classification of UCLA Center for European and Eurasia Studies was used. This variable was included based on Greece government's concentrated aid allocation to specific regions (OECD, 2006, p. 25) as well as analysis prior studies on Korea's regional attention (e.g. Koo \& Kim, 2011; Sohn et al., 2011). The latter is from the World Bank which was used to identify if Korea favors them in aid giving.

- Distance is a variable that measures the distance from Athens, the capital of Greece, or Seoul, the capital of Korea, to that of each recipient country. The data is from Centre d'Etudes Prospectives et d'Informations Internationales (CEPII). Both the region and distance variable were used in two different regression analyses to measure verify donors' policy orientation towards their neighboring countries.

First, the aggregate dataset using all years and countries are analyzed. Second is to divide the recipient countries into three income groups by low income, lower middle income and upper and high income countries following the World Bank's categorization. Methodologically, this study utilizes random-effect Tobit model, following that of prior studies on aid determinants (e.g. Alesina and Dollar (2000), Berthélemy and Tichit (2004), Kim and Oh (2012)). It has the advantage of coding zero values as random variables as a lower limit (Kim and Oh, 2012: 262).

Table 2. Comparison of Greece and Korea's aid determinants

\begin{tabular}{lll}
\hline & Korea & Greece \\
& $\mathbf{1 9 8 7 - 2 0 1 1}$ & $\mathbf{1 9 9 6 - 2 0 0 8}$ \\
\hline Ln_Income & $0.603^{* * *}$ & $0.470^{* * *}$ \\
& $(0.118)$ & $(0.159)$ \\
${\text { (Ln_Income })^{2}}^{2}$ & $-0.049^{* * *}$ & $-0.032^{* * *}$ \\
Ln_Pop & $(0.008)$ & $(0.011)$ \\
& 0.177 & 0.304 \\
$\left(\right.$ Ln_Pop) ${ }^{2}$ & $(0.109)$ & $(0.196)$ \\
& $-0.006^{*}$ & -0.008 \\
Ln_Growth & $(0.003)$ & $(0.006)$ \\
\hline
\end{tabular}




\begin{tabular}{lll}
\hline \multirow{2}{*}{ Ln_Trade } & $(0.008)$ & $(0.008)$ \\
& $0.032^{* * *}$ & 0.003 \\
Life Expectancy & $(0.006)$ & $(0.006)$ \\
& $0.010^{* * *}$ & 0.002 \\
Freedom House Index & $(0.002)$ & $(0.003)$ \\
& -0.007 & $-0.022^{* *}$ \\
Political Terror Scale & $(0.007)$ & $(0.010)$ \\
& -0.004 & $-0.015^{*}$ \\
Region & $(0.008)$ & $(0.008)$ \\
& $0.167^{* * *}$ & $1.067^{* * *}$ \\
Constant & $(0.065)$ & $(0.124)$ \\
& $-3.491^{* * *}$ & 1,138 \\
No. Obs & $(0.991)$ & 508 \\
Censored & 1,489 & 0.818 \\
Rho & 347 & $-4.629^{* * *}$ \\
\hline
\end{tabular}

Source: ODA disbursement per capita (OECD Statistical Database); Income, Population, Growth rate and Life expectancy (World Development Indicators); Trade (Eurostat and Korea Statistical Information Service, per capita terms); Freedom House Index (Freedom House); Political Terror Scale (PTS, Amnesty International based); Region (UCLA Center for European and Eurasia Studies for Greece, World Bank for Korea)

Note: Tobit Random Effect. Normal distribution and censoring at zero. Standard errors in parenthesis.

$* * * \mathrm{p}<0.01, * * \mathrm{p}<0.05, * \mathrm{p}<0.1$

Table 2 shows the empirical findings of the two donors' aid determinants with aid and trade data in per capita terms. Both countries display similarities by showing the typical signs of economic and commercial motivations of a donor. That is, as positive and significant correlation to income, population and trade variables suggest, Korea and Greece give more aid to countries with higher income, larger population and more trade albeit at a decreasing rate. Greek aid is also correlated to positive growth rate which solidifies the argument above.

Although the correlation between aid and growth is more significant for Greece, both display strong national interest in its aid allocation.

As for life expectancy, the result is positive in both cases although it is significant only in case of Korea. For the Freedom House Index and Political Terror Scale, both of which represent the state of rule of law and human rights protection in the recipient countries, are negative, with significant results for Greece. As the lower number represents better situation for both indices, the negative correlation means aid is being given to more stable and free countries. Overall, the results for three indicators suggest that both Korea and Greece reward countries with good performances and governance.

Both donors' strong regional interest is evident in their aid practices. In case of Greece, it gives more aid to Eastern European countries. This seems to reflect the Greek government's foreign policy of focusing on the stability of Southeast European countries as stated in the Hellenic Plan for the Economic Reconstruction of the Balkans (HiPERB). Such geographical focus is mainly due to the fact that Greece is located nearby countries in post-conflict or economic transition (OECD, 2006, p. 10) whose stability and security affect Greece. Korea's regional concentration on Southeast Asian countries is also reflected in its policies where 14 out of 26 priority countries are located in Asia (OECD, 2012, p. 28) and major aid allocation to the region (OECD, 2012, p. 50). Such objective is reflected in its aid pattern where more aid goes to these countries. Berthélemy and Tichit (2004) suggest small donors specialize their aid based on self-interest due to their small aid budget that cannot cover large number of recipients. Overall, aside from growth, Korea and Greece are similar in most aspects. They both project economic and political interests in aid allocation while also favoring stable countries. 
Table 3 provides findings on how the two donors' aid motivations are portrayed in recipient countries divided by their income level. Following the World Bank's categorization, the recipient countries were divided into three income groups: low income, lower middle income and upper and high income countries. In addition, based on the result of Table 2, the distance variable was used only for Greece to verify in what income group closeness would matter. Since Central and Eastern European countries are located close to Greece, the variable that measures the distance between the capital of Greece and that of the recipient country was used instead of the regional variable. The same goes for Korea, whose regional interest resulted in positive and significant correlation in Table 2. Analyses will show if the two donors are consistent in pursuing their strategic focus in different income countries.

Whereas both Korea and Greece's aid was highly correlated to the income level in Table 2, it was not the case for Korea, especially in low income countries. Result for Greece was consistent in all income levels, demonstrating its pattern of targeting larger income countries regardless of economic status. Korea, on the other hand, had negative yet insignificant correlation to income in low income country group which means at least in low income countries, Korea disregards income as an important criterion of its aid. The result is the opposite in lower and upper middle income countries where the income level becomes important.

Aside from the per capita income, the results for economic interest of Korea and Greece in terms of growth rate and trade are mixed. To reiterate, Korea's aid is negatively and insignificantly correlated to growth rate in all income groups whereas the case of Greece is the contrary. As for the trade, Korea disburses more aid to its trading partners, more so in the bottom two income groups while Greece does not account for trade volume in low income countries. Hence, the three variables; income, growth rate and trade, show a mixture of contrasting results in determining the two donor's self-interest. However, what is clear is that the correlation becomes more significantly geared towards domestic interest for both donors in lower, upper middle and high income countries.

Same goes for life expectancy, Freedom House Index and Political Terror Scale. If the donors targeted better performing countries in general, it was not the case for Korea. Greece's outcome was consistent in all income levels with significant results in the first two income groups. This signifies that in low and lower middle income group, more stabilized countries received more aid from Greece. Korea also awarded countries with higher life expectancy and better protection of freedom but PTS was found to have not had any significant relationship.

The two countries' priority on neighboring countries is retained as well. Two countries give more aid to countries located closer to them but the result is significant only for Greece. That is, Greece displays projects stronger geographical interest even to low and lower middle income countries. In addition to the significant correlation for regional dummy in Table 2, the result for distance in Table 3 fortifies Greece's priority on its neighboring region. When looking only at the significant results, both countries tend to portray less economic interest in low income groups with the exception of Korea's trade correlation, and more in lower and upper middle and high income countries in terms of income and trade. As for social and political development, it is more rewarded in low and lower middle income group.

Table 3. Aid determinants of Greece and Korea by recipient country's income level

\begin{tabular}{lllllll}
\hline & Low & \multicolumn{3}{c}{ Lower Middle } & \multicolumn{2}{c}{ Upper Middle and High } \\
& Korea & Greece & Korea & Greece & Korea & Greece \\
& $\mathbf{1 9 8 7 - 2 0 1 1}$ & $\mathbf{1 9 9 6 - 2 0 0 8}$ & $\mathbf{1 9 8 7 - 2 0 1 1}$ & $\mathbf{1 9 9 6 - 2 0 0 8}$ & $\mathbf{1 9 8 7 - 2 0 1 1}$ & $\mathbf{1 9 9 6 - 2 0 0 8}$ \\
\hline Ln_Income & -0.117 & 0.507 & $0.629^{* * *}$ & $0.453^{* *}$ & $7.165^{* * *}$ & $4.527^{*}$ \\
& $(0.454)$ & $(0.567)$ & $(0.121)$ & $(0.221)$ & $(2.338)$ & $(2.651)$ \\
(Ln_Income) $^{2}$ & 0.015 & -0.032 & $-0.051^{* * *}$ & $-0.032^{* *}$ & $-0.416^{* * *}$ & $-0.267^{*}$ \\
& $(0.038)$ & $(0.047)$ & $(0.008)$ & $(0.015)$ & $(0.132)$ & $(0.149)$ \\
Ln_Pop & $0.438^{*}$ & 0.223 & $0.198^{*}$ & 0.374 & 0.078 & -0.126 \\
& $(0.237)$ & $(0.376)$ & $(0.118)$ & $(0.239)$ & $(0.146)$ & $(0.146)$ \\
(Ln_Pop) $^{2}$ & $-0.014^{*}$ & -0.006 & $-0.006^{*}$ & -0.009 & -0.003 & 0.004 \\
& $(0.007)$ & $(0.011)$ & $(0.004)$ & $(0.007)$ & $(0.005)$ & $(0.005)$ \\
Ln_Growth & -0.016 & 0.006 & -0.010 & $0.025^{* *}$ & -0.031 & 0.036 \\
\hline
\end{tabular}




\begin{tabular}{lllllll}
\hline & $(0.010)$ & $(0.010)$ & $(0.008)$ & $(0.010)$ & $(0.022)$ & $(0.025)$ \\
Ln_Trade & $0.024^{* * *}$ & -0.009 & $0.034^{* * *}$ & 0.007 & -0.022 & $0.019^{*}$ \\
Life Expectancy & $(0.008)$ & $(0.008)$ & $(0.006)$ & $(0.009)$ & $(0.014)$ & $(0.012)$ \\
& $0.012^{* * *}$ & 0.005 & $0.011^{* * *}$ & $0.010^{* * *}$ & 0.004 & 0.004 \\
Freedom House & $(0.003)$ & $(0.004)$ & $(0.002)$ & $(0.003)$ & $(0.005)$ & $(0.006)$ \\
Index & $-0.019^{*}$ & $-0.039^{* * *}$ & -0.008 & $-0.034^{* * *}$ & 0.019 & -0.009 \\
& $(0.011)$ & $(0.014)$ & $(0.008)$ & $(0.012)$ & $(0.013)$ & $(0.014)$ \\
Political Terror & 0.011 & -0.007 & -0.004 & $-0.022^{*}$ & 0.004 & -0.036 \\
Scale & $(0.010)$ & $(0.012)$ & $(0.008)$ & $(0.011)$ & $(0.020)$ & $(0.022)$ \\
& -0.000 & $-0.000^{* * *}$ & -0.000 & $-0.000^{* * *}$ & -0.000 & -0.000 \\
Distance & $(0.000)$ & $(0.000)$ & $(0.000)$ & $(0.000)$ & $(0.000)$ & $(0.000)$ \\
& 602 & 378 & 1,489 & 1,282 & 300 & 210 \\
No. Obs & 92 & 182 & 347 & 706 & 150 & 128 \\
Censored & 0.589 & 0.888 & 0.388 & 0.754 & 0.120 & 0.006 \\
Rho & &
\end{tabular}

Note. Tobit Random Effect. Normal distribution and censoring at zero. Standard errors in parenthesis. *** $\mathrm{p}<0.01, * * \mathrm{p}<0.05, * \mathrm{p}<0.1$

Source: ODA Disbursement (OECD Statistical Database); Income, Population, Growth rate and Life expectancy (World Development Indicators); Trade (Eurostat and Korea Statistical Information Service); Freedom House Index (Freedom House); Political Terror Scale (PTS, Amnesty International based); Distance (CEPII)

\section{Korea's Challenges in Development Cooperation}

There may be some possible implications for having such mixed results in this study. First, the two donors may not have any strong humanitarian motivations in their aid. This may be due to prioritization of other interest (e.g. geographic, political) over economic interest. For instance, majority of their partner countries are from nearby region as their development policies suggest. Second, in combination with the positive correlation to income, population, trade and growth in Table 2, the two countries can simply focus more on higher income countries, which can be indicative of insignificant economic correlation for low income countries and positive correlations in upper two income groups.

Last but not least, it may have to do with proliferating aid channels of Korea. Not only does Korea have a bifurcated system, but when compared to other emerging donors, it is the most proliferated donor with most number of recipients (Dreher et al., 2011, 1953). However, a critical problem that can arise from having a bifurcated system is that it hinders the effective aid allocation and thus may continue incoherent aid practices. 


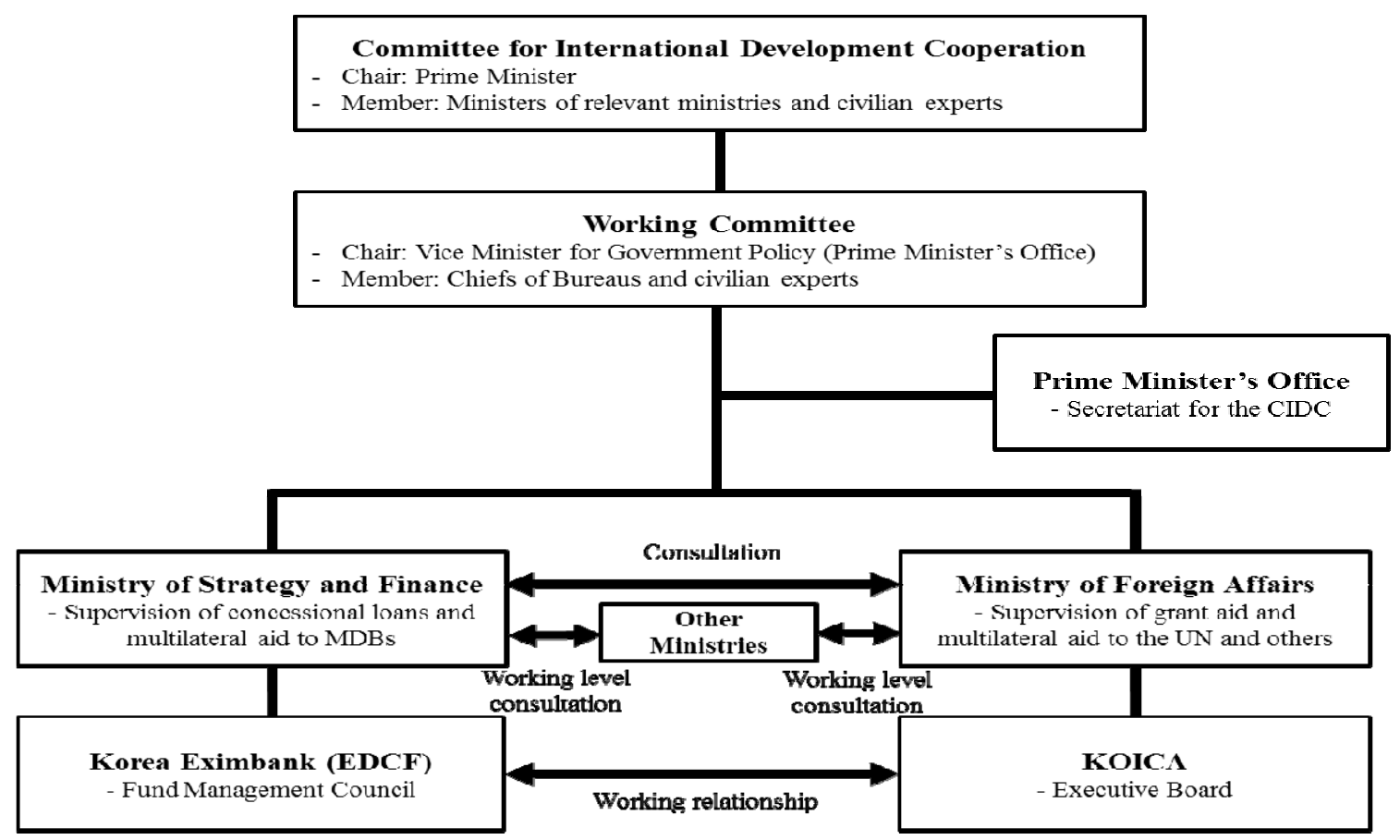

Figure 2. Korea's Institutional Framework of ODA

Source: ODA Korea, 2013. (http://www.odakorea.go.kr/eng.structure.Overview.do)

As can be seen from Figure 2, the Committee for International Development Cooperation is in charge of making a main decision for Korea's ODA budget. Thus, it is responsible for designing the annual ODA plan which involves finalizing the planning and budgeting process. However, at the national level, the Ministry of Strategy and Finance in Korea is responsible for managing and allocating the national budget to other ministries and public organizations, including the Korea International Cooperation Agency (KOICA) and the Economic Development Cooperation Fund (EDCF). It denotes that, in the end, scaling up the aid volume depends on main decisions made at the Budget Office of the Ministry of Strategy and Finance. Nevertheless, often times too much vested authority of one ministry generate problems such as aid fragmentation and ineffective aid practices.

According to the 2012 Peer Review Report of the OECD for Korea, the mandate of the CIDC is limited since ODA projects and programs that are already approved for grants or loans by the Inter-Agency Committees and ratified by the CIDC can be rejected if the Budget Office of the Ministry of Strategy and Finance uses its veto power against projects or programs that do not match with its criteria for project approval (OECD, 2012). Meeting the project approval criteria to implement the ODA-funded activities is very important in assuring the effective aid practices. However, owing to other ministries' awareness of the Ministry of Strategy and Finance's capacity, the line ministries directly ask for project approvals from the Budget Office of the Ministry of Strategy and Finance without receiving approval from the Inter-Agency Grants Committee. This issue results in unpredictable ODA project approval process and in opaque budget execution process.

In addition to the constrained authority of the CIDC, the aid fragmentation is exacerbated with a large number of governments' and public institutions' participation in ODA projects. As it is analyzed in Table 4, in 2013, the amount of aid executed by the Korean government was KRW 20,410.7 million in total. However, compared to the national budget available for foreign assistance, more than 27 departments of the Korean government participated in ODA-funded activities in 2012 and 2013. If a number of local governments and their affiliated public institutions are included in the table, the number of participants engaging in ODA-funded activities will significantly increase.

Also, when examining the ODA budget allowed for the Ministry of Strategy and Finance (including EDCF) and the Ministry of Foreign Affairs (including KOICA), the portion concentrated to those two ministries account for approximately $89 \%$ of Korea's ODA budget in 2013. This phenomenon implies that, except for the Ministry of Strategy and Finance and the Ministry of Foreign Affairs in Korea, the Korean government's too many ministries or offices provide too little ODA to too many priority recipient countries. Thus, such intensified aid 
fragmentation will aggravate the coordination among departments and may potentially deepen the rivalry between the Ministry of Strategy and Finance and the Ministry of Foreign Affairs to exercise stronger leverage when implementing the ODA projects in partner countries. Thus, such aid fragmentation and ODA projects which do not align with the CIDC's annual ODA plan but are directly approved by the Budget Office will create more obstacles in improving Korea's aid effectiveness and in raising the role of Korea in the international development cooperation.

Table 4. Status of Allocated ODA budget for the Korean ministries and government departments in 2012 and 2013

\begin{tabular}{|c|c|c|c|c|c|c|}
\hline & \multicolumn{3}{|c|}{2012} & \multicolumn{3}{|c|}{2013} \\
\hline & Bilateral & Multilateral & Total & Bilateral & Multilateral & Total \\
\hline Prime Minister's Office & 87 & 8 & 95 & 33.6 & 20.9 & 54.5 \\
\hline $\begin{array}{l}\text { Ministry of Strategy and } \\
\text { Finance } \\
\text { (including EDCF) }\end{array}$ & 6,554 & 3,946 & 10,500 & 7076.8 & $3,982.8$ & $11,059.6$ \\
\hline $\begin{array}{l}\text { Ministry of Education, } \\
\text { Science and Technology }\end{array}$ & 404 & 97 & 501 & 521.6 & 88.2 & 609.8 \\
\hline $\begin{array}{l}\text { Ministry of Foreign } \\
\text { Affairs (Note 4) } \\
\text { (including KOICA) }\end{array}$ & 5,375 & 785 & 6,160 & $5,690.4$ & 1,489 & $7,179.4$ \\
\hline Ministry of Justice & 11 & - & 11 & 10.7 & 2.8 & 13.5 \\
\hline $\begin{array}{l}\text { Ministry of Public } \\
\text { Administration and } \\
\text { Security }\end{array}$ & 61 & - & 61 & 67.1 & - & 67.1 \\
\hline $\begin{array}{l}\text { Ministry of Culture, } \\
\text { Sports and Tourism }\end{array}$ & 28 & 4 & 32 & 43.1 & 25.4 & 68.5 \\
\hline $\begin{array}{l}\text { Ministry for Food, } \\
\text { Agriculture, Forestry } \\
\text { and Fisheries }\end{array}$ & 126 & 105 & 231 & 150 & 90 & 240 \\
\hline $\begin{array}{l}\text { Ministry of Knowledge } \\
\text { Economy }\end{array}$ & 96 & 17 & 113 & 97.5 & 15.1 & 112.6 \\
\hline $\begin{array}{l}\text { Ministry of Health and } \\
\text { Welfare }\end{array}$ & 107 & 172 & 279 & 126 & 196.4 & 322.4 \\
\hline $\begin{array}{l}\text { Ministry of } \\
\text { Environment }\end{array}$ & 73 & 49 & 122 & 101 & 85.1 & 186.1 \\
\hline $\begin{array}{l}\text { Ministry of Employment } \\
\text { and Labor }\end{array}$ & 5 & 98 & 103 & 4.5 & 11.3 & 15.8 \\
\hline $\begin{array}{l}\text { Ministry of Gender } \\
\text { Equality and Family }\end{array}$ & 9 & 50 & 59 & 10 & 45.2 & 55.2 \\
\hline $\begin{array}{l}\text { Ministry of Land, } \\
\text { Transport and Maritime } \\
\text { Affairs }\end{array}$ & - & 1 & 1 & - & 1.1 & 1.1 \\
\hline $\begin{array}{l}\text { Korea Communications } \\
\text { Commission }\end{array}$ & 46 & 13 & 59 & 41.6 & 19 & 60.6 \\
\hline $\begin{array}{l}\text { Korea Fair Trade } \\
\text { Commission }\end{array}$ & 2 & - & 2 & 1.7 & - & 1.7 \\
\hline $\begin{array}{l}\text { Anti-Corruption and } \\
\text { Civil Rights }\end{array}$ & 1 & - & 1 & 0.9 & - & 0.9 \\
\hline
\end{tabular}




\begin{tabular}{|c|c|c|c|c|c|c|}
\hline \multicolumn{7}{|l|}{ Commission of Korea } \\
\hline $\begin{array}{l}\text { Ministry of Patriots and } \\
\text { Veterans Affairs }\end{array}$ & 1 & - & 1 & 1.8 & - & 1.8 \\
\hline Korea Customs Service & 23 & - & 23 & 28.4 & 3.5 & 31.9 \\
\hline Statistics Korea & 6 & 1 & 7 & 7.4 & 1.2 & 8.6 \\
\hline $\begin{array}{l}\text { Korean National Police } \\
\text { Agency }\end{array}$ & 13 & 15 & 28 & - & 14.3 & 14.3 \\
\hline $\begin{array}{l}\text { Cultural Heritage } \\
\text { Administration }\end{array}$ & 3 & 8 & 11 & 7.5 & 4 & 11.5 \\
\hline $\begin{array}{l}\text { Rural Development } \\
\text { Administration }\end{array}$ & 121 & 5 & 126 & 138.9 & 5.2 & 144.1 \\
\hline Korea Forest Service & 46 & 23 & 69 & 69.1 & 27.1 & 96.2 \\
\hline $\begin{array}{l}\text { Korean Intellectual } \\
\text { Property Office }\end{array}$ & 3 & 10 & 13 & 3.8 & 10.1 & 13.9 \\
\hline $\begin{array}{l}\text { Korea Meteorological } \\
\text { Administration }\end{array}$ & 10 & 1 & 11 & 17.5 & 18.5 & 36 \\
\hline $\begin{array}{l}\text { National Election } \\
\text { Commission }\end{array}$ & 2 & - & 2 & 3.6 & - & 3.6 \\
\hline Total & 13,213 & 5,408 & 18,621 & $14,254.5$ & $6,156.2$ & $20,410.7$ \\
\hline
\end{tabular}

Note. The unit for the budget is KRW Million.

Source: Comprehensive Implementation Plan for International Development Cooperation 2013 (Committee for International Development Cooperation, 2012).

\section{Conclusion}

The limitation of the study was that, due to a lack of data on Greece's ODA activities and its projects, it was somewhat difficult to conjecture the upcoming challenges of Greece's ODA. However, overall, Greece and Korea display similar patterns of aid disbursement. They favor recipients with higher income level, with larger population, closer trade ties, better social development, protection of freedom and human rights, and nearby located neighbors. Moreover, when taking a closer look by dividing the recipient countries into three different income groups, the attributes above were also reflected and more so in lower and upper middle and high income groups.

Three reasons explain such mixed results of two countries' aid allocation patterns in this study. First, the two donors may not have any strong humanitarian motivations in their aid. Second, the two countries propend to allocate more aid to higher income countries, which can be indicative of insignificant economic correlation for low income countries but positive correlations in upper two income groups. Finally, in case of Korea, proliferating aid channels of Korea hinders the effective aid allocation and thus may continue incoherent aid practices that are interest-driven.

Although Korea is putting its best effort to implement sound aid practices for the international development cooperation, aid fragmentation that is induced by too many government departments' participation in ODA-funded projects and obscure processes for aid project approval are challenges which Korea must overcome. Thus, in order to raise the important role of Korea in the current paradigm of international development cooperation, Korea at the institutional level needs to figure out how it can foster collaboration among different government departments and ministries for establishing clearer ODA-funded project approval criteria. Furthermore, more active interaction between two major government departments, the Ministry of Strategy and Finance and the Ministry of Foreign Affairs, should be developed much further so that Korea can effectively perform its sound coherent aid practices and efficiently allocate more aid to the ones who are in need.

\section{References}

Alesina, A., \& Dollar, D. (2000). Who Gives Foreign Aid to Whom and Why? Journal of Economic Growth, 5(1), 33-63. http://dx.doi.org/10.1023/A:1009874203400 
Berthélemy, J. C., \& Tichit, A. (2004). Bilateral Donors' Aid Allocation Decisions-A Three-Dimensional Panel Analysis. International Review of Economics \& Finance, 13(3), 253-274. http://dx.doi.org/10.1016/j.iref.2003.11.004

Claessens, S., Cassimon, D., \& Van Campenhout, B. (2009). Evidence on Changes in Aid Allocation Criteria. The World Bank Economic Review, 23(2), 185-208. http://dx.doi.org/10.1093/wber/lhp003

Committee for International Development Cooperation. (2012). Comprehensive Implementation Plan for International Development Cooperation 2013. Retrieved May 28, 2015, from http://www.odakorea.go.kr/hz.blltn2.YearPlanSlPL.do?brd_seq=3\&b1_ltn_div=oda

Dreher, A., Nunnenkamp, P., \& Thiele, R. (2011). Are 'New' Donors Different? Comparing the Allocation of Bilateral Aid between Non DAC and DAC Donor Countries. World Development, 39(11), 1950-1968. http://dx.doi.org/10.1016/j.worlddev.2011.07.024

Doucouliagos, H., \& Manning, E. (2009). The Allocation of Development Aid Assistance: Do New Donors have Old Motives? Deakin University School Working Paper Economic Series, 17, 1-26.

Kim, E. M., \& Oh, J. (2012). Determinants of Foreign aid: The Case of South Korea. Journal of East Asian Studies, 12(2), 251-273.

Lee, K. W. (2005). Analysis on the Determinants of Korea's ODA Disbursement. Korea Eximbank Overseas Economy, 10, 4-21.

Lee, K. W. (2012). Do Emerging Donors Allocate Aid as DAC Members Do? The Case of Korea in the Millennium Era. Journal of International Development, 24, 977-988. http://dx.doi.org/10.1002/jid.2872

Neumayer, E. (2003). The Determinants of Aid Allocation by Regional Multilateral Development Banks and United Nations Agencies. International Studies Quarterly, 47(1), 101-122. http://dx.doi.org/10.1111/1468-2478.4701005

ODA Korea. (2013). Structure. Retrieved September 5, 2013, from http://www.odakorea.go.kr

OECD. (2006). Greece: Development Assistance Committee Peer Review 2006. Paris: Organisation for Economic Co-operation and Development.

OECD. (2011). Greece: Development Assistance Committee Peer Review 2011. Paris: Organisation for Economic Co-operation and Development.

OECD. (2012). Korea: Development Assistance Committee Peer Review 2012. Paris: Organisation for Economic Co-operation and Development.

Sohn, H. S., Ahn, S., \& Hong, J. (2011). What Matters in Determining Korean ODA Allocation. Korean Political Science Review, 45(6), 45-68.

\section{Notes.}

Note 1. In 2013, Iceland (March) and Czech Republic (May) became the newest OECD DAC members.

Note 2. Korea's priority partner countries are as follows: In Asia, there are 14 (Azerbaijan, Bangladesh, Cambodia, Indonesia, Laos, Mongolia, Nepal, Pakistan, Philippines, Solomon Islands, Sri Lanka, Timor-Leste, Uzbekistan, Vietnam). In Africa, there are 8 (Cameroon, DR Congo, Ethiopia, Ghana, Mozambique, Nigeria, Rwanda, and Uganda). Latin American countries are 4 (Bolivia, Colombia, Paraguay and Peru).

Note 3. Although aid commitment better reflects donor's intentions (Berthélemy and Tichit 2004, 254), disbursement was used in this study as Korea's commitment data for 1994 was unavailable in the OECD database and using such data may create biased result.

Note 4. Global fund for poverty eradication is included in the budget. In March 2013, the name of the Ministry of Foreign Affairs and Trade in Korea was changed into the Ministry of Foreign Affairs. For more information, please visit www.mofa.go.kr/introduce/oranization/budget/history/index.jsp?mofat=001\&menu=m_70_20_10.

\section{Copyrights}

Copyright for this article is retained by the author(s), with first publication rights granted to the journal.

This is an open-access article distributed under the terms and conditions of the Creative Commons Attribution license (http://creativecommons.org/licenses/by/3.0/). 